\title{
MODEL PENDIDIKAN OLAH RAGA BERBASIS KETERAMPILAN GERAK DASAR
}

\author{
Agi Ginanjar ${ }^{12}$, Adang Suherman ${ }^{3}$, Tite Juliantine ${ }^{3}$, dan Yusuf Hidayat ${ }^{3}$ \\ ${ }^{1}$ Pendidikan Jasmani Kesehatan dan Rekreasi STKIP Nahdlatul Ulama Indramayu \\ ${ }^{2}$ Sekolah Pascasarjana Universitas Pendidikan Indonesia \\ ${ }^{3}$ Fakultas Pendidikan Olahraga dan Kesehatan Universitas Pendidikan Indonesia \\ email: agiginanjar@stkipnu.ac.id
}

\begin{abstract}
Abstrak
Penelitian ini bertujuan untuk menguji perbedaan pengaruh Sport Education Model (SEM) atau model pendidikan olah raga menggunakan racquet sports antara siswa yang memiliki Fundamental Movement Skills (FMS) tinggi dan siswa yang memiliki FMS rendah terhadap orientasi olahraga siswa SMP. Metode yang digunakan dalam penelitian ini adalah metode penelitian eksperimen murni dengan posttest-only control design. Populasi dalam penelitian ini siswa SMP sebanyak 174 orang dengan sampel sebanyak 40 orang menggunakan simple random sampling. Program ini meliputi tiga tahap, yaitu skill/tactical development, inter/intra team games with practices, dan postseason dengan menggunakan gabungan dari berbagai model pembelajaran, seperti direct instruction, cooperative, dan peer. Instrumen penelitian untuk FMS menggunakan tes FMS dan untuk orientasi olah raga menggunakan Sport Orientation Questionnaire (SOQ). Uji signifikansi dengan independent samples t-test. Hasil penelitian menyatakan bahwa terdapat pengaruh SEM pada siswa dengan FMS tinggi dan FMS rendah terhadap orientasi olah raga siswa SMP sehingga penelitian ini menyimpulkan bahwa SEM memberikan pengaruh terhadap orientasi olah raga siswa. Daya saing merupakan subskala yang paling berperan dalam orientasi olah raga siswa.

Kata kunci: sport education model, fundamental movement skill, orientasi olah raga
\end{abstract}

\section{SPORT EDUCATION MODEL WITH FUNDAMENTAL MOVEMENT SKILLS}

\begin{abstract}
This study was aimed at examining the differences in the effect of SEM using racquet sports between the students who have high FMS and students who have low FMS towards the sports orientation of junior high school. The method used in this study was the true experimental research method with posttest-only control group design. The population in this study consisted of 174 junior high school students with a sample of 40 people taken using the simple random sampling method. This program included three stages, namely skill/tactical development, inter/intra-team games with practices, and postseason by using a combination of various learning models, such as direct instruction, cooperative learning, and peer learning. The instruments for examining the FMS was an FMS test while for examining sports orientation was the Sport Orientation Questionnaire (SOQ). Independent samples t-test was used to test the significance. The results show that SEM had an influence on students' sports orientation. Competitiveness is the subscale that plays the most role in student sports orientation.
\end{abstract}

Keywords: sport education model, fundamental movement skill, sports orientation 


\section{PENDAHULUAN}

Kompetitif dapat dikatakan sebagai limpahan dari kompetisi. Kompetisi ditandai dengan adanya persaingan. Kompetitif berhubungan dengan kompetisi (persaingan), bersifat kompetisi (persaingan) (Setiawan, 2012). Kompetitif sangat dibutuhkan dalam kehidupan seharihari, ini berguna menghadapi persaingan di pasar global (Ali, 2013). Dalam pendidikan jasmani, mempertahankan tingkat persaingan dapat meningkatkan program; menghapus semua bentuk kompetisi tidak banyak membantu siswa untuk hidup di luar sekolah mereka (Heidorn et al., 2019).

Dalam pendidikan jasmani yang bersifat kompetitif, sadar atau tidak sadar setiap anak akan menampilkan performa terbaiknya untuk bersaing mendapatkan hasil yang terbaik. Jika tidak ada unsur kompetisi, siswa kurang memiliki alasan untuk melakukan upaya terbaik mereka dalam permainan. Di mata mereka itu tidak masalah (Heidorn et al., 2019). Nicholls dalam teori tujuan pencapaian menyatakan bahwa dalam konteks pencapaian, orang berusaha untuk menampilkan kemampuan tinggi dan menghindari untuk menunjukkan kemampuan rendah (Jamshidi, Hossien, Sajadi, Safari, \& Zare, 2011).

Kompetisi adalah alat motivasi yang bagus untuk kelas pendidikan jasmani (Heidorn et al., 2019). Cara kita mengukur hasil belajar kadang-kadang melalui kompetisi dalam beberapa cara, ini tidak selalu berarti mengidentifikasi pemenang dan pecundang (Heidorn et al., 2019). Kompetisi merupakan panduan untuk mengejar keunggulan dalam olahraga dan masyarakat sehingga dapat memberikan wawasan yang signifikan (Heidorn et al., 2019) dan nilai olahraga kompetitif di sekolah diperlukan (Almond, 2014).
Di seluruh Eropa, olahraga kompetitif semakin dilihat sebagai elemen penting dalam kurikulum pendidikan jasmani (Almond, 2014, p. 51). Asosiasi negatif seputar permainan olahraga di tingkat remaja atau dewasa menimbulkan pertanyaan serius tentang validitas olahraga kompetitif (Almond, 2014, p. 51). Untuk mengetahui kompetitif seseorang dalam mengikuti kompetisi olahraga (orientasi olahraga) diperlukan alat untuk mengukurnya. Sport Orientation Questionnaire ( $S O Q$ ) mengukur berbagai proses yang digunakan orang untuk menilai kompetensi dan mengevaluasi keberhasilan dalam konteks olahraga (Gill \& Deeter, 1988; Jamshidi et al., 2011; Farshad, Jasem, \& Mohammad, 2013; Sheikh, Afshari, \& Sheikh, 2011).

Dalam pembelajaran pendidikan jasmani siswa kurang terlibat dalam mengikuti proses pembelajaran sehingga banyak menimbulkan isu dalam proses pembelajaran pendidikan jasmani. Hampir seluruh guru pendidikan jasmani di setiap sekolah memakai model pembelajaran langsung. Guru memegang kendali dalam pembelajaran sedangkan siswa mengikuti pembelajaran yang diberikan oleh guru (Ginanjar, 2015). Pembelajaran pendidikan jasmani yang dipusatkan pada model pengajaran langsung menghasilkan tingkat ketidakaktifan murid yang tinggi (Roberts \& Fairclough, 2011).

Proses pembelajaran pendidikan jasmani di tingkat satuan pendidikan Sekolah Menengah Pertama (SMP) terdapat kendala mengurangnya tingkat aktivitas. Penurunan tingkat keterlibatan fisik ini sangat tajam selama SMP (antara usia 13 dan 15) (Jaakkola \& Washington, 2013). Padahal, jika dikaji lebih dalam, penilaian aktivitas fisik harus ditunjang dengan adanya Fundamental Movement Skills (FMS) sebagai faktor 
yang berpotensi signifikan dalam tingkat partisipasi aktivitas fisik remaja (Jaakkola \& Washington, 2013). FMS terdiri atas tiga komponen utama, yakni locomotor skills, balance skills, dan manipulative skills (Jaakkola \& Washington, 2013; Kalaja, Jaakkola, Liukkonen, \& Digelidis, 2012). FMS sudah dimiliki oleh siswa baik yang tinggi maupun rendah.

Berdasarkan kelemahan dan kelebihan dalam pendidikan jasmani yang telah dipaparkan, konsekuensi negatif dari persaingan dapat dihilangkan jika kompetisi diajarkan dan digunakan dengan benar di kelas (Ginanjar, 2018b). Guru pendidikan jasmani harus menyediakan model positif untuk mengajar siswa sesuai dengan persaingan (Layne, 2014). Persaingan memberikan rasa aman untuk mendukung pembelajaran yang bermanfaat untuk siswa pada masa sekarang dan akan datang ketika diajarkan dengan tepat (Layne, 2014). Oleh karena itu, untuk membantu siswa menjadi lebih aktif selama pelajaran olahraga, guru harus mampu dan mau memberikan pengajaran berkualitas dengan strategi pengajaran yang sesuai (Bryan \& Solmon, 2012).

Salah satu alat untuk membantu guru dalam PBM adalah dengan mengunakan model pembelajaran (Ginanjar, 2015). Salah satu model pembelajaran yang diasumsikan dapat meningkatkan aktivitas kompetitif dalam mengikuti PBM adalah Sport Education Model (SEM) yang dirancang untuk memberikan anakanak dengan persaingan yang sesuai perkembangan (Siedentop, Hastie, \& Van der Mars, 2011, p. vii). SEM bertujuan untuk mendorong setiap individu untuk mengembangkan keterampilan dan pemahaman yang diperlukan untuk berpartisipasi dalam kegiatan olahraga. Siswayang terlibat dalam SEM akanmenjadi terpelajar, antusias, dan olahragawan yang berkompeten (Siedentop, 1994, p. 4) melalui enam karakteristik SEM yakni musim, afiliasi, kompetisi formal, acara puncak, penyimpanan catatan, dan perayaan (Siedentop, 1994, p. 9). Hasil penelitian yang lain pun menyatakan bahwa SEM lebih baik daripada model pembelajaran langsung terhadap orientasi olahraga (Ginanjar, 2018b).

Dalam proses pembelajaran SEM dapat digunakan dalam cabang olahraga yang menggunakan raket atau disebut racquet sports. Racquet sports terdiri atas badminton, racqquetball, table tennis, tennis (Siedentop, 1994, p. 105). Oleh karena itu, cabang olahraga yang digunakan di dalam penelitian ini menggunakan badminton. Alasan menggunakan cabang olahraga badminton karena olahraga ini sangat populer di Indonesia dan guru mengetahui aturan dan tata cara permainan cabang olahraga tersebut. Selain itu, dalam permainan badminton akan ada persaingan untuk menjadi pemenang dalam pertandingan. Berdasarkan pemaparan di atas, tujuan penelitian ini untuk mengetahui perbedaan pengaruh SEM menggunakan racquet sports antara siswa yang memiliki FMS tinggi dan siswa yang memilki FMS rendah terhadap orientasi olahraga siswa SMP.

\section{METODE}

Metode penelitian menggunakan true experiment dengan posttest-only control design. Populasi dalam penelitian ini sebanyak 174 siswa SMP kelas VII. Seluruh populasi dites FMS terlebih dahulu melalui flamingo standing test, rolling test, leaping test, shuttle running test, rope jumping test, figure-eight dribbling test, dan accuracy throwing test (Jaakkola \& Washington, 2013; Kalaja et al., 2012). Hasil tes di-ranking. Jumlah populasi 
dibagi menggunakan $27 \%$ atas dan $27 \%$ bawah untuk mengetahui kelompok FMS tinggi dan FMS rendah. Dari hasil tersebut didapat 34 siswa pada kelompok FMS tinggi dan 34 siswa pada kelompok FMS rendah sehingga didapat sampel sebanyak 68 siswa. Berkaitan dengan desain penelitian yang digunakan, untuk penelitian eksperimen sederhana yang menggunakan kelompok eksperimen dan kelompok kontrol maka jumlah anggota masing-masing sampel antara $10 \mathrm{~s} / \mathrm{d} 20$ (Sugiyono, 2016, p. 132). Oleh karena itu, peneliti mengambil 20 orang siswa sebagai sampel, baik siswa yang memiliki FMS tinggi maupun siswa yang memiliki FMS rendah dengan menggunakan teknik simple random sampling sehingga total sampel sebanyak 40 orang.

Program SEM dalam penelitian ini meliputi tiga tahap, yaitu skill/tactical development, inter/intra team games with practices, dan postseason (Perlman, 2012) dengan menggunakan gabungan dari berbagai model pembelajaran, seperti direct instruction, cooperative, dan peer (Ginanjar, 2018a; Metzler, 2000, p. 254; Siedentop, 1998).

Instrumen yang digunakan untuk mengukur orientasi olahraga menggunakan SOQ (Gill \& Deeter, 1988; Jamshidi et al., 2011; Farshad et al., 2013; Sheikh et al., 2011). SOQ terdiri atas tiga subskala, yakni competitiveness (daya saing) dengan 13 item, winning orientation (orientasi kemenangan) dengan 6 item, dan goal orientation (orientasi tujuan) dengan 6 item dengan total seluruh item sebanyak 25 item soal. Analisis menggunakan analisis faktor konfirmatori dengan bantuan aplikasi IBM AMOS 24. Berdasarkan hasil analisis diperoleh 15 item soal dapat digunakan dengan rincian subskala daya saing sebanyak 7 item, orientasi kemenangan sebanyak 3 item, dan orientasi tujuan sebanyak 5 item dengan nilai $\mathrm{CMIN}=$ 144,79 dan $\mathrm{DF}=87$ dengan $\mathrm{CMIN} / \mathrm{DF}=$ $1,66<2$. RMSEA $=0,059$ di antara 0,05 0,08 dengan nilai NFI, PNFI, CFI, IFI, RFI, GFI, AGFI dengan masing-masing nilai 0,$85 ; 0,71 ; 0,93 ; 0,94 ; 0,82 ; 0.90$; dan 0,86 yang diindikasikan diterima sehingga model pengukuran adalah baik (Ginanjar, 2018b).

Untuk melihat perbedaan rata-rata, simpangan baku, dan varian dari setiap data yang dianalisis dilakukan dengan bantuan IBM Statistical Package for the Social Sciences (SPSS) Statistics 24. Uji normalitas merupakan salah satu uji prasyarat yang digunakan untuk mengetahui apakah data tersebut berdistribusi normal atau tidak yang dianalisis dengan menggunakan shapirowilk dengan bantuan IBM SPSS Statistics 24. Uji homogenitas digunakan untuk mengetahui apakah suatu data atau sampel yang diambil berasal dari varian yang homogen atau tidak yang dianalisis menggunakan lavene statistic dengan bantuan IBM SPSS Statistics 24. Untuk mengetahui signifikansi data yang didapat dianalisis menggunakan independent samples t-test dengan bantuan IBM SPSS Statistics 24.

\section{HASIL PENELITIAN DAN PEMBAHASAN}

Hasil statistik deskriptif pada kelas eksperimen didapat rerata sebesar 34,65; $s=5,09$; dan $S=25,92$. Pada kelas kontrol didapat didapat rerata sebesar 27,85; $s=$ 5,11 ; dan $S=26,23$. Uji normalitas pada kelas eksperimen sebesar 0,93 dengan signifikansi $0,15>0,05$; pada kelas kelas kontrol sebesar 0,96 dengan signifikansi $0,60>0,05$. Berdasarkan data ini, dapat dikatakan bahwa data kedua kelompok tersebut berdistribusi normal. Berdasarkan hasil uji homogenitas diperoleh nilai sebesar 0,06 dengan signifikansi 0,81>0,05. 
Nilai ini mengandung arti bahwa kedua kelompok tersebut berasal dari data yang sama atau homogen.

Berdasarkan hasil uji signifikansi diperoleh nilai $\mathrm{t}_{\text {hitung }}=4,22$ dengan signifikansi $0,00<0,05$. Nilai ini mengandung arti bahwa terdapat perbedaan pengaruh SEM menggunakan racquet sports antara siswa yang memiliki FMS tinggi dan siswa yang memiliki FMS rendah terhadap orientasi olahraga siswa SMP.

Hasil penelitian pada kelas eksperimen menggunakan SEM dengan FMS tinggi dan pada kelas kontrol menggunakan SEM dengan FMS rendah. Dalam penentuannya, siswa FMS tinggi dan rendah tersebut dengan menggunakan tes FMS (Jaakkola \& Washington, 2013; Kalaja et al., 2012) yang terdiri atas locomotor skills, balance skills, dan manipulative skills.

Locomotor skills terdiri atas leaping test tata cara melakukan tes dengan melompat dengan kaki sejajar dan mendarat dengan kaki posisi sejajar, penilaian tes tersebut dengan mengukur panjang lompatan, diukur dalam sentimeter, dari posisi awal sampai tumit kaki terjauh saat mendarat. Shuttle running test tata cara melakukan tes dengan lari bolak-balik sebanyak 10 kali dengan jarak 5 meter dan kedua kaki harus melewati batas yang telah ditentukan, penilaian waktu yang dihitung dalam meneyelesaikan lari bolak-balik sebanyak 10 kali. Rope jumping test tata cara melakukan tes dengan cara melompat tali dengan satu kaki (awalan bisa dengan menggunakan kaki kanan/kiri), melakukan lompatan selama 30 detik. Partisipan melompat dengan salah satu kaki. Setelah 15 detik diberi sinyal untuk mengganti kaki dan menyelesaikan tes. Penilaian tes menghitung jumlah lompatan yang berhasil dalam 30 detik (kaki kanan 15 detik dan kaki kiri 15 detik).
Balance skills terdiri atas flamingo standing test, yakni tata cara melakukan tes berdiri dengan satu kaki sambil menyeimbangkan diri pada balok kayu ukuran panjang $50 \mathrm{~cm}$, tinggi $4 \mathrm{~cm}$, dan lebar $3 \mathrm{~cm}$ selama 30 detik. Penilaian tes dihitung jumlah berapa kali partisipan kehilangan keseimbangan dalam 60 detik (kaki kanan 30 detik dan kaki kiri 30 detik). Rolling test tata cara melakukan tes berdiri dengan melakukan roll depan sejauh 5 meter kemudian kembali lagi melakukan roll ke posisi awal dengan secepat mungkin. Penilaian dengan menghitung total waktu yang ditempuh dalam melakukan roll sejauh 5 meter ke depan dan ke belakang.

Manipulative skills terdiri atas figureeight dribbling test tata cara melakukan tes dengan menggiring bolavoli pada track angka delapan. Pertama menggunakan kaki selama 30 detik kemudian ketika ada aba-aba "ganti" langsung menggiring menggunakan tangan selama 30 detik dengan jarak setiap patok 2,5 meter. Penilaian dengan cara menghitung jumlah menyelesaikan putaran selama satu menit. Accuracy throwing test tata cara melakukan tes melakukan 10 kali melempar bola tennis ( 5 kali tangan kanan dan 5 kali tangan kiri) dari patok menuju target lingkaran dengan jarak lempar sepanjang 5 meter untuk mendapatkan poin sebanyakbanyaknya dengan poin 3 masuk kedalam lingkaran $20 \mathrm{~cm}$, dua masuk ke dalam $40 \mathrm{~cm}$, dan satu masuk kedalam $60 \mathrm{~cm}$ ). Penilaian tes dengan menghitung jumlah total poin lemparan yang masuk dari 10 kali lemparan. Berdasarkan kepada kebutuhan dan keterbatasan penelitian maka peneliti mengambil 20 orang siswa yang memiliki FMS tinggi yang dijadikan sebagai kelas eksperimen dan 20 orang siswa yang memiliki FMS rendah yang dijadikan sebagai kelas konrol. 
Program pembelajaran yang digunakan di dalam penelitian ini dengan menggunakan program SEM yang digunakan dalam penelitian ini menggunakan tiga tahap, yakni skill/tactical development, inter/intra team games with practices, dan postseason (Perlman, 2012) dengan menggunakan gabungan dari berbagai model pembelajaran yaitu direct instruction, cooperative, dan peer (Ginanjar, 2018a; Metzler, 2000, p. 254; Siedentop, 1998). Penggunaaan SEM dapat memiliki fungsi ganda, yakni sebagai kurikulum pembelajaran dan sebagai model pembelajaran.

Pada tahap skill/tactical development lebih menekankan kepada kemampuan keterampilan gerak olahraga yang akan digunakan. Pada fase ini digunakan direct instruction dan cooperative tipe Student Team Achievement Division (STAD). Pada tahap ini ada lima kali pertemuan dan pada pertemuan pertama digunakan untuk memenuhi kebutuhan dalam karakteristik SEM. Hal ini juga diterapkan dalam pengenalan cabang olahraga bulu tangkis, keterlibatan peran, pemberian awareness, mengidentifikasi dan menyiapkan bahan, perumusan musim olahraga, dan membuat musim meriah dengan menggunakan model pembelajaran direct instruction. Hasil yang didapat dalam pertemuan ini, baik kelas eksperimen maupun kelas kontrol yang terdiri dari 20 orang setiap kelompoknya. Dua orang sebagai pencatat pertandingan, satu orang sebagai publikasi, dan dua orang sebagai wasit. Kemudian 15 orang dibagi ke dalam tiga kelompok sehingga setiap kelompok terdiri dari lima orang. Dari setiap tim satu orang bertugas sebagai manager dan pelatih dan empat orang sebagai pemain termasuk kapten tim.

Adapun pertemuan kedua sampai pertemuan keempat merupakan pertemuan untuk latihan keterampilan dalam bermain bulu tangkis dengan materi service, forehand dan backhand, lob dengan menggunakan model pembelajaran kooperatif STAD. Pada pertemuan kelima latihan keterampilan dalam bermain bulu tangkis dengan materi smash menggunakan model pembelajaran direct instruction. Total pertemuan dalam tahap ini sebanyak lima pertemuan. Secara kesulurahn pada kelas eksperimen pada tahap skill/tactical development terlihat sangat jelas bahwa siswa yang memiliki FMS tinggi dapat lebih berkonsentrasi dalam melakukan latihan. Mereka juga tidak mengalami kesulitan dalam melakukan teknik-teknik bermain bulu tangkis.

Berbeda dengan kelas kontrol pada FMS rendah, siswa masih kurang memilki teknik bermain bulu tangkis yang baik. Indikasinya terlihat dengan masih banyaknya kesalahan dalam melakukan gerakan sehingga mereka terlihat kurang aktif dalam melakukan proses pembelajaran.

Pada tahap inter/intra team games with practices menekankan kepada kompetisi di dalam kelompok untuk menghadapi pertandingan antarkelompok pada tahap selanjutnya. Pada fase ini menggunakan cooperative tipe Teams Games Tournaments (TGT) yang mana dalam TGT terdapat pertandingan dalam tim dan pertandingan antartim didalam sebuah kelompok, peer digunakan untuk mengetahui siswa yang memliki kemampuan yang baik (hasil pertandingan antartim di dalam kelompoknya) melatih siswa yang kurang memiliki kemampuan yang baik.

Pada pertemuan keenam sampai kesembilan dengan menggunakan cooperative tipe TGT. Setiap kelompok terdapat beberapa tim yang saling melakukan pertandingan atau bisa disebut dengan 
pertandingan di dalam tim. Kemudian, hasil pertandingan dalam tim tersebut peringkat pertama dalam sebuah tim melawan peringkat pertama dari kelompok lain dan peringkat kedua melawan kedua dan peringkat ketiga melawan ketiga dari setiap kelompok. Hal ini bisa disebut juga dengan pertandingan antartim. Hasil pertandingan dari pertemuan keenam sampai dengan kesembilan tim yang memiliki poin paling baik dari setiap hasil pertemuan tersebut pada pertemuan kesepuluh melatih tim yang kurang memiliki poin dengan menggunakan peer.

Secara keseluruhan pada tahap inter/intra team games with practices memberikan hasil yang menarik apalagi pada pertemuan keenam sampai dengan kesembilan. Pada kelas eksperimen mereka menikmati permainan bulu tangkis dan dapat dikatakan pertandingan terlihat menarik dengan kemampuan yang dimiliki oleh setiap siswa. Hal ini berbeda pada kelas control. Pada kelompok kontrol siswa cenderung banyak berdiam diri saat pertandingan. Artinya, dapat dikatakan mereka kurang berusaha dan mungkin terlihat kurang serius untuk bermain secara maksimal dan juga banyak waktu yang terbuang hanya untuk memulai pertandingan setelah shuttlecock jatuh.

Tahap akhir atau disebut postseason merupakan refleksi dari tahapan-tahapan sebelumnya. Tahapan ini merupakan akhir dari musim pembelajaran menggunakan kompetisi antarkelompok dengan adanya turnamen. Turnamen dilaksanakan dengan sistem bertemu sebanyak empat putaran. Peringkat satu dan dua pada pertemuan 15 melakukan pertandingan final dan setelah melakukan final dilakukan perayaan dengan nominasi yang terdiri atas juara, peringkat dua, peringkat tiga, pemain terbaik, dan tim terbaik.
Secara keseluruhan dalam tahap postseason, hampir sama dengan apa yang terjadi pada tahap inter/intra team games with practices. Pada tahap ini dilakukan dengan menggunakan kompetisi penuh pada kelas eksperimen. Siswa sangat menikmati pertandingan dalam setiap pertemuan tim pada penyisihan sebelum memasuki final, mampu menikmati pertandingan dan setiap tim bersaing secara ketat, dapat saling mengalahkan satu sama lainnya sehingga pemenang dalam kelompok eksperimen tidak dapat diprediksi. Berbeda dengan kelas eksperimen, pada kelompok kontrol permainan kurang berjalan menarik, banyak waktu terbuang untuk memulai pertandingan dan hasil akhir juara pun sudah dapat diprediksi tim yang mengajar tim lain dengan menggunakan peer pada pertemuan 10 menjadi pemenangnya.

Berkaitan dengan instrumen penelitian yang menggunakan SOQ terdiri atas tiga subskala, yakni daya saing, orientasi kemenangan, dan orientasi tujuan. Seseorang yang memiliki orientasi kemenangan memiliki keinginan selalu untuk menang dan menghindari kekalahan dalam olahraga, sedangkan seseorang yang memiliki orientasi tujuan fokus pada pencapaian tujuan pribadi dalam mengikuti kompetisi olahraga dan lebih mengevaluasi keberhasilan. Orientasi tujuan dan orientasi kemenangan mencerminkan pilihan dan respons individu selama latihan dan kegiatan olahraga (Gill \& Deeter, 1988; Jamshidi et al., 2011; Farshad et al., 2013; Sheikh et al., 2011).

Pada daya saing sangat dipengaruhi pilihan seseorang untuk berpartisipasi dalam olahraga kompetitif. Individu yang sangat berorientasi pada daya saing termotivasi untuk bergabung dan mencari prestasi dalam olahraga kompetitif(Gill \& Deeter, 1988; Jamshidi et al., 2011). Jadi, seseorang yang lebih mengutamakan daya 
saing, cenderung untuk menginginkan prestasi dalam mengikuti olahraga yang bersifat kompetitif.

Penelitian ini memiliki tujuan untuk menguji perbedaan pengaruh SEM menggunakan racquet sports antara siswa yang memilki FMS tinggi dan siswa yang memilki FMS rendah terhadap orientasi olahraga siswa SMP. Hasil penelitian menyatakan bahwa SEM menggunakan racquet sports pada siswa yang memilki FMS tinggi memberikan tingkat signifikansi yang lebih tinggi dibandingkan dengan siswa yang memilki FMS rendah terhadap orientasi olahraga. Jadi siswa yang memiliki FMS tinggi dapat dengan mudah memiliki keterampilan gerak sehingga siswa lebih dapat dengan mudah berkonsentrasi pada kegiatan kompetisi. Kemudian bahwa dukungan dan dorongan FMS dan aktivitas fisik yang berkorelasi dengan pendidikan jasmani merupakan cara yang masuk akal untuk sehat sepanjang hidup. Kemahiran FMS juga berpengaruh positif terhadap aktivitas belajar siswa (Barnett, van Beurden, Morgan, Brooks, \& Beard, 2009; Capio, Sit, Eguia, Abernethy, \& Masters, 2015; Zask et al., 2012). Dalam penelitian ini siswa yang memiliki FMS tinggi lebih baik daripada siswa yang memiliki FMS rendah.

Seperti yang telah dijelaskan sebelumnya, dalam proses pembelajaran yang telah dilakukan di dalam penelitian ini terlihat bahwa siswa yang memilki FMS tinggi lebih aktif mengikuti proses pembelajaran dibandingkan dengan siswa yang memiliki FMS rendah. Ini dapat disebabkan karena bulutangkis merupakan cabang olahraga yang kompleksitas geraknya menggunakan seluruh tubuh sehingga siswa dengan FMS tinggi dapat dengan mudah bermain bulutangkis tanpa kesulitan melakukan teknik-teknik dasar bermain bulutangkis.

Siswa dengan FMS tinggi lebih cepat menguasai gerakan dan dapat melakukan service dengan benar ketika melakukan service. Berbeda halnya dengan siswa yang memiliki FMS rendah, mereka masih ada yang gagal dalam melakukan gerakan service. Tidak hanya service dalam teknik-teknik yang lain, seperti forehand, backhand, lob, dan smash juga siswa dengan FMS tinggi lebih cepat menguasai dibandingkan dengan siswa yang memilki FMS rendah. Ini dapat dikaitkan dengan pernyataan penguasaan FMS juga akan mempengaruhi keterampilan kecabangan olahraga (O'Keeffe, Harrison, \& Smyth, 2007). Selain itu, hal ini juga dapat disebabkan bahwa pemilihan cabang olahraga, yakni permainan bulutangkis dapat bersifat individu seperti satu lawan satu atau dua lawan dua.

Setiap pemain atau pasangan mengambil posisi berseberangan pada kedua sisi jaring di lapangan bulutangkis yang dibatasi oleh net di bagian tengah untuk memisahkan daerah permainan yang satu dengan lainnya yang memiliki tujuan utama untuk memenangkan pertandingan dengan cara mengumpulkan angka hingga mencapai angka untuk mengakhiri permainan. Oleh karena itu, hasil ini mendukung dan memperluas bahwa model pembelajaran dapat digunakan dalam pembelajaran pendidikan jasmani (Ginanjar, 2015; 2018c).

Lebih lanjut, hasil yang berkaitan dengan SEM yang menggunakan cabang individu, Grant (Siedentop, 1994, p. 83) menggunakan cabang olahraga tenis, Bell (Siedentop, 1994, p. 47) menggunakan cabang olahraga senam. SEM menggunakan tarian dalam pembelajaran (Graves \& Townsed, 2000). SEM menggunakan cabang olahraga atletik (Pereira, Araújo, Farias, Bessa, \& Mesquita, 2016). Penelitian ini juga memberikan pandangan bahwa SEM dapat digunakan dalam olahraga 
yang bersifat kompetisi dan memberikan dukungan bahwa SEM dapat digunakan dalam orientasi olahraga (Ginanjar, Suherman, Juliantine, \& Hidayat, 2019). Dengan menggunakan SEM daya saing menggunakan kompetisi itu lebih intens, adil, bahkan menarik dan menyenangkan (Bennett \& Hastie, 1997).

Hasil yang menarik berkaitan dengan orientasi olahraga yang didapat menggunakan SOQ yang terdiri atas subskala daya saing, orientasi kemenangan, dan orientasi tujuan. Pada kelas eksperimen dan kelas kontrol subskala daya saing merupakan subskala yang paling berperan dalam orientasi olahraga dengan nilai rata-rata masing-masing 2,39 pada kelas ekperimen dan 1,96 pada kelas control. Subskala orientasi tujuan merupakan subskala kedua yang paling berperan dalam orientasi olahraga dengan nilai rata-rata masing-masing 2,25 pada kelas ekperimen dan 1,8 pada kelas kontrol.
Subskala orientasi kemenangan merupakan subskala ketiga yang paling berperan dalam orientasi olahraga dengan nilai rata-rata masing-masing 2,23 pada kelas ekperimen dan 1,72 pada kelas kontrol.

Hasil tersebut berbeda dengan pernyataan bahwa pencapaian dalam kompetisi olahraga (orientasi olahraga) tergantung pada orientasi tujuan (Farshad et al., 2013; Sheikh et al., 2011). Ini bisa disebabkan oleh pemilihan cabang olahraga bulu tangkis yang mana siswa berperan secara individu sehingga penelitian ini memberikan pandangan yang sesuai dengan pernyataan bahwa daya saing sangat menentukan seseorang untuk berpartisipasi dalam olahraga kompetitif. Individu yang sangat berorientasi pada daya saing termotivasi untuk mencari prestasi dalam olahraga kompetitif (Jamshidi et al., 2011). Untuk gambar perbedaan pada setiap kelompok tersebut dapat dilihat pada Gambar 1.

Gambar 1. Grafik Orientasi Olahraga pada Kelas Eksperimen dan Kelas Kontrol

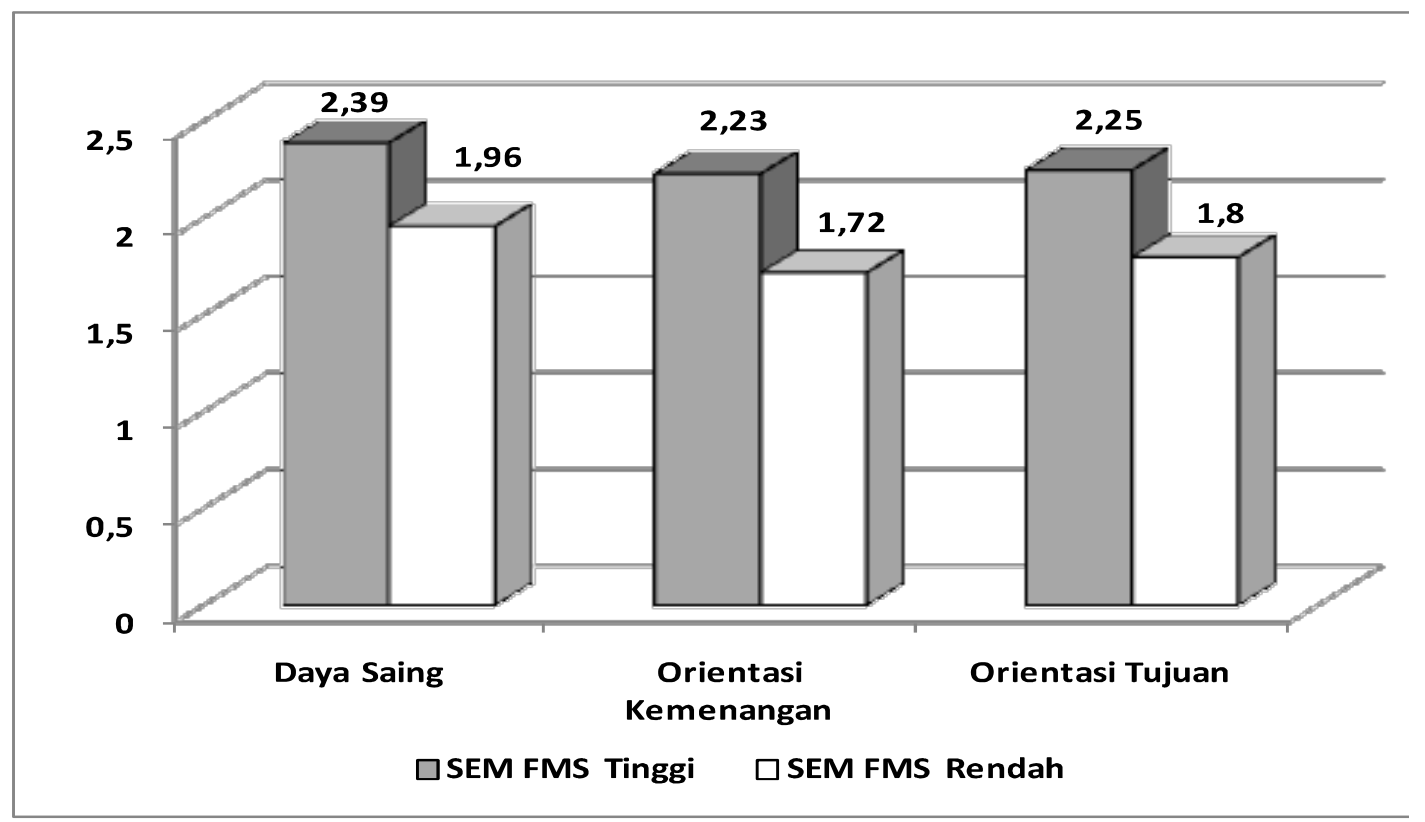




\section{SIMPULAN}

Berdasarkan hasil penelitian dan pembahasan dapat disimpulkan bahwa terdapat perbedaan pengaruh SEM menggunakan racquet sports antara siswa yang memiliki FMS tinggi dan siswa yang memilki FMS rendah terhadap orientasi olahraga siswa SMP. Artinya, terdapat pengaruh SEM dengan FMS terhadap orientasi olahraga siswa SMP. Dalam pencapaian kompetitif yang berorientasi olahraga dalam pembelajaran pendidikan jasmani khususnya, dapat meningkat apabila guru menggunakan model pembelajaran SEM. Siswa dengan FMS tinggi lebih baik dari pada siswa dengan FMS rendah dan daya saing merupakan subskala yang paling berperan dalam orientasi olahraga siswa SMP.

Rekomendasi yang dapat diajukan adalah sebagai berikut. Pertama, guru, pelatih, praktisi olahraga dan orang tua diharapkan selalu melatih dan memperhatikan FMS terhadap setiap kegiatan yang dilakukan siswa. Hal ini dilakukan dengan tujuan agar siswa dapat lebih mudah dalam mengatasi permasalahan yang dialami dalam proses pembelajaran dan untuk kehidupan siswa sehari-hari. Kedua, perlu pula dilakukan penelitian lebih lanjut terhadap siswa dengan FMS tinggi apakah benar lebih baik dari pada siswa yang memilki FMS rendah dalam aktivitas fisik dengan menggunakan cabang olahraga lain selain bulutangkis. Ketiga, jumlah kelas yang sedikit di dalam penelitian ini sehingga temuan yang didapat berpotensi tidak dapat digeneralisasikan. Oleh karena itu, perlu penelitian lebih lanjut dengan menambah jumlah partisipan agar temuan dapat digeneralisasikan.

\section{DAFTAR PUSTAKA}

Ali, M. (2013). Analisis kesiapan SMK RSBI dalam peningkatan daya saing lulusan. Jurnal Kependidikan, 43(1), 78-86. https://doi.org/10.21831/ jk.v43i1.2257.

Almond, L. (2014). Does competitive sport have educational validity in physical education? Science \& Sports, 29, S51. https://doi.org/10.1016/j. scispo.2014.08.102.

Barnett, L. M., van Beurden, E., Morgan, P. J., Brooks, L. O., \& Beard, J. R. (2009). Childhood motor skill proficiency as a predictor of adolescent physical activity. Journal of Adolescent Health, 44(3), 252-259. https://doi. org/10.1016/j.jadohealth.2008.07.004.

Bennett, G., \& Hastie, P. A. (1997). A Sport education curriculum model for a collegiate physical activity course. Journal of Physical Education, Recreation \& Dance, 68(1), 39-44. https://doi.org/10.1080/07303084.19 97.10604876.

Bryan, C. L., \& Solmon, M. A. (2012). Student motivation in physical education and engagement in physical activity. Journal of Sport Behavior, 35, 267-285.

Capio, C. M., Sit, C. H. P., Eguia, K. F., Abernethy, B., \& Masters, R. S. W. (2015). Fundamental movement skills training to promote physical activity in children with and without disability: A pilot study. Journal of Sport and Health Science, 4(3), 235-243. https:// doi.org/10.1016/j.jshs.2014.08.001.

Farshad, T., Jasem, M., \& Mohammad, M. (2013). Validation of an instrument for measuring athletes 'sport orientation in iranian martial artists community. Middle-East Journal of Scientific Research, 18(6), 738743. https://doi.org/10.5829/idosi. mejsr.2013.18.6.75140.

Gill, D. L., \& Deeter, T. E. (1988). Development of the sport orientation 
questionnaire. Research Quarterly for Exercise and Sport, 59(3), 191-202. https://doi.org/10.1080/02701367.19 88.10605504 .

Ginanjar, A. (2015). The influence of inquiry method in motivating the SMP' student. Jurnal Kependidikan, 45(2), 123-129. http://dx.doi.org/10.21831/ jk.v45i2.7489.

Ginanjar, A. (2018a). Implementasi sport education model dalam peningkatan aktivitas fisik siswa SMP. Jurnal Kependidikan Jasmani dan Olahraga, 2(1), 52-61.

Ginanjar, A. (2018b). Pengaruh sport education model bulu tangkis terhadap orientasi olahraga siswa SMP. BIORMATIKA, 4(02), 280287. Diunduh dari http://ejournal. unsub.ac.id/index.php/FKIP/article/ view/379/347.

Ginanjar, A. (2018c). The tactical games modelsand motivation learningof physical fitness the vocational school students. Jurnal Kependidikan: Penelitian dan Inovasi Pembelajaran, 2(2), 409-419. https://doi. org/10.21831/jk.v2i2.10746.

Ginanjar, A., Suherman, A., Juliantine, T., \& Hidayat, Y. (2019). Sports orientation during learning team or individual sports using a sport education model. Jurnal Cakrawala Pendidikan, 38(2). https://doi. org/10.21831/cp.v38i2.24021.

Graves, M. A., \& Townsed, J. S. (2000). Applying the sport education model to dance. Journal of Physical Education, Recreation \& Dance, 71(8), 50-54. https://doi.org/10.1080/07303084.20 00.10605192 .

Heidorn, B., Hopkins, E., Davis, C., Mitchell, B., Colon, M., Hubert, C., ... Fischer, K. (2019). What is the place of competition in elementary and secondary physical education curricula? Journal of Physical Education, Recreation and Dance, 90(1), 61-64. https://doi.org/10.1080 /07303084.2019.1537436.

Jaakkola, T., \& Washington, T. (2013). The relationship between fundamental movement skills and self-reported physical activity during finnish junior high school. Physical Education and Sport Pedagogy, 18(5), 492-505. https://doi.org/10.1080/17408989.20 12.690386 .

Jamshidi, A., Hossien, T., Sajadi, S. S., Safari, K., \& Zare, G. (2011). The relationship between sport orientation and competitive anxiety in elite athletes. Procedia-Social and Behavioral Sciences, 30, 1161-1165. https://doi. org/10.1016/j.sbspro.2011.10.226.

Kalaja, S. P., Jaakkola, T. T., Liukkonen, J. O., \& Digelidis, N. (2012). Physical education and sport pedagogy development of junior high school students' fundamental movement skills and physical activity in a naturalistic physical education setting. Physical Education and Sport Pedagogy, 17(4), 411-428. https://doi.org/10.1080/1740 8989.2011.603124.

Layne, T. E. (2014). Competition within physical education: Using sport education and other recommendations to create a productive, competitive environment. Strategies: A Journal for Physical and Sport Educators, 27(6), 3-7. https://doi.org/10.1080/0892456 2.2014.960124.

Metzler, M. W. (2000). Intructional models for physical education. Massachusetts: Allyn and Bacon.

O'Keeffe, S. L., Harrison, A. J., \& Smyth, P. J. (2007). Transfer or specificity? An applied investigation into the relationship between fundamental 
overarm throwing and related sport skills. Physical Education \& Sport Pedagogy, 12(2), 89-102. https://doi. org/10.1080/17408980701281995.

Pereira, J., Araújo, R., Farias, C., Bessa, C., \& Mesquita, I. (2016). Sport education and direct instruction units : Comparison of student knowledge development in athletics. Journal of Sports Science and Medicine, 15, 569-577.

Perlman, D. (2012). The influence of the sport education model on amotivated students' in-class physical activity. European Physical Education Review, 18(3), 335-345. https://doi. org/10.1177/1356336X12450795

Roberts, S., \& Fairclough, S. (2011). Observational analysis of student activity modes, lesson contexts and teacher interactions during games classes in high school (1116 years) physical education. European Physical Education Review, 17(2), 255-268. https://doi. org/10.1177/1356336X11420222.

Setiawan, E. (2012). Kamus besar bahasa Indonesia (KBBI): Kamus versi online/ Daring (dalam jaringan). Jakarta: Badan Pengembangan dan Pembinaan Bahasa, Kemendikbud (Pusat Bahasa). Diunduh dari https://kbbi.web.id/.
Sheikh, M., Afshari, J., \& Sheikh, H. (2011). Comparing sport orientation between individual and team sports and its relation to sport participation motivation. American Journal of Scientific Research, 30, 28-35.

Siedentop, D. (1994). Sport education: Quality PE through positive sport experiences. Champaign: Human Kinetics.

Siedentop, D. (1998). What is Sport education and how does it work? Journal of Physical Education, Recreation \& Dance, 69(4), 18-20. https://doi.org/10.1080/07303084.19 98.10605528.

Siedentop, D., Hastie, P. A., \& Van Der Mars, H. (2011). Complete guide to sport education. Champaign: Human Kinetics.

Sugiyono. (2016). Metode penelitian pendidikan (Pendekatan kuantitatif, kualitatif dan $R \& D$ ). Bandung: Alfabeta.

Zask, A., Barnett, L. M., Rose, L., Brooks, L. O., Molyneux, M., Hughes, D., ... Salmon, J. (2012). Three year followup of an early childhood intervention: Is movement skill sustained? International Journal of Behavioral Nutrition and Physical Activity, 9(1), 1-9. https://doi.org/10.1186/14795868-9-127. 